January 2012

\title{
List of Conference Speakers
}

List of Conference Speakers

Follow this and additional works at: https://scholarlycommons.law.case.edu/cuslj

\section{Recommended Citation}

List of Conference Speakers, List of Conference Speakers, 36 Can.-U.S. L.J. v (2011)

Available at: https://scholarlycommons.law.case.edu/cuslj/vol36/iss1/3

This Foreword is brought to you for free and open access by the Student Journals at Case Western Reserve University School of Law Scholarly Commons. It has been accepted for inclusion in Canada-United States Law Journal by an authorized administrator of Case Western Reserve University School of Law Scholarly Commons. 


\title{
CANADA-UNITED STATES LAW INSTITUTE CONFERENCE \\ on
}

\author{
THE CANADA-UNITED STATES REgUlatory REgIME: \\ REVIEW, REFORM, RECOVERY
}

April 8-10, 2010

\section{LIST OF CONFERENCE SPEAKERS}

Hon. James Blanchard has dedicated his life to public service and law, serving with distinction as governor of the State of Michigan, ambassador to Canada and a member of the U.S Congress. During eight years as Michigan's chief executive (1983-91) Blanchard was named one of the best governors in America by U.S. News and World Report for returning the state to financial solvency and creating innovative new programs to meet the needs of its citizens. As ambassador (1993-96), Blanchard managed a broad range of issues between the U.S. and Canada, receiving the prestigious Foreign Affairs Award for Public Service for his work. In 1997, Blanchard authored Behind the Embassy Door-Canada, Clinton and Quebec, a book highlighting his experiences. Blanchard was an assistant attorney general of Michigan for five years and then served four terms as a member of Congress (1975-1983) leading the successful fight to save the Chrysler Corporation. Currently, he is co-chair of Government Affairs for the global law firm of DLA Piper and chairman of the Meridian International Center, a leading public diplomacy, non-profit center in Washington, D.C. He is also on the board of directors of several public and private organizations. Jim and Janet Blanchard reside in Beverly Hills, Michigan.

Timothy E. Boyle is currently vice president and chief counsel - Competition and Trade Regulation at Eaton Corporation. Mr. Boyle handles antitrust and competition issues, export and import regulatory issues, and internal investigations for Eaton. Eaton Corporation is a diversified power management company with 2009 sales of $\$ 11.9$ billion. Eaton manufactures electrical components and systems for power quality, distribution, and control; hydraulics components, systems, and services for industrial and mobile equipment; aerospace fuel, hydraulics, and pneumatic systems for commercial and military use; and truck and automotive drivetrain and powertrain systems. Eaton has approximately 70,000 employees and sells products to customers in more than 150 countries. Prior to joining Eaton in 2002, Mr. Boyle was a partner at Howrey LLP, in Washington, D.C., where he practiced for sixteen years. Mr. Boyle graduated, with honors, from Duke University School of Law in 1986.

Donald B. Cameron, Jr. is recognized with distinction in Chambers Global: The World's Leading Lawyers for Business (since 2007), Chambers USA: America's Leading Lawyers for Business (since 2005), and The International Who's Who of Business Lawyers (since 2006), and has more than three decades of experience representing multinational businesses, foreign governments, foreign trade associations, and United States importers in litigation under United States antidumping, countervailing duty, and safeguards law. He also advises clients from around the globe in international trade disputes and market access issues, and has particular experience defending clients in industry sectors that are politically sensitive. He regularly practices before the U.S. Department of Commerce, the U.S. International Trade Commission, the Office of the U.S. Trade Representative, the U.S. Court of International Trade, and the U.S. Court of Appeals for the Federal Circuit. In addition, he advises clients on World Trade Organization (WTO) proceedings and has participated in WTO Panel and Appellate Body proceedings on behalf of clients and their member governments. He has also defended clients in NAFTA Chapter 19 proceedings and has argued before NAFTA Panels. Mr. Cameron and his partner, Julie Mendoza, also advised the Government of Korea in the successful WTO challenges to the U.S. safeguard actions on line pipe and certain steel products (AB-2001-9 and AB-2003-3). As counsel for foreign manufacturers, Mr. Cameron has advised and assisted foreign governments in a variety of 
bilateral and multilateral trade negotiations, most prominent being the steel Voluntary Restraint Arrangements negotiations, bilateral subsidies negotiations, and the OECD shipbuilding negotiations. Mr. Cameron received his J.D. (1974) from Vanderbilt University and B.A. (1971) from Kenyon College. He received his LL.M. (1975) from the Vrije Universiteit, Brussels, Program on International Legal Cooperation in Brussels.

Chios Carmody has taught at The University of Western Ontario Faculty of Law since 1999, where he teaches courses in public international law, international trade law, and international business transactions. He also serves as Canadian Director of the Canada-United States Law Institute. He has been a visiting professor at Georgetown University Law Center and an Emile Noël Fellow at the Jean Monnet Center for Regional and International Economic Law \& Justice, NYU Law School. He holds LL.B. (Ottawa), LL.M. (Michigan), and S.J.D. (Georgetown) degrees and is a member of the Bars of Ontario and New York.

Cyndee Todgham Cherniak is counsel in the International Trade Law, the Business Law, the Tax Law, and the Environment, Energy \& Emissions Trading Groups in Lang Michener's Toronto office, which became McMillan on January 1, 2011. Her practice includes: international law, including World Trade Organization (WTO) and Regional Trade Agreements (RTA) analysis, interpretations, and opinions, government relations strategies, and dispute settlement, North American Free Trade Agreement (NAFTA) verifications, value for duty, tariff classification, import and export controls and sanctions, bilateral restraint agreements, bilateral investment treaties, textile references, international protection of intellectual property rights, antidumping and countervailing duties, safeguard actions, government procurement, investor-state disputes, the Foreign Extraterritorial Measures Act, border and national security, food and product safety, anti-corruption and anti-bribery, and compliance programs/codes of conduct. Cyndee also has expertise in commodity tax (i.e., goods and services tax (GST)), Ontario retail sales tax, Ontario employer health tax, Ontario land transfer tax, excise tax, gasoline and fuel taxes, and customs duties. Cyndee is known as an international lawyer who works closely with other lawyers, inhouse counsel, international financial institutions, trade associations, non-governmental organizations, and governments.

David Crane is an award-winning Canadian writer on economic, political, and environmental issues. He is a member of the National Statistics Council, an advisory body to Statistics Canada, the President's International Advisory Council at the University of Toronto, the President's Advisory Council at Victoria University, and the Advisory Board of the Canada-United States Law Institute. A graduate of the University of Toronto, Mr. Crane has an Arbor Award from the University of Toronto and honorary doctorates from Wilfrid Laurier University and Victoria University (part of the University of Toronto). He was awarded the Queen's Jubilee Medal for his contribution to Canadian life and a Social Work Doctoral Award by the Social Work Doctors' Colloquium. He is a member of the Davos Circle, an association of long-term participants in the World Economic Forum. Author of several books, including The Next Canadian Century, The Canadian Dictionary of Business and Economics, and Controlling Interest, he is currently writing a book on how Canada should position itself in the global economy.

Richard O. Cunningham is senior international trade partner in the Washington office of Steptoe \& Johnson LLP, where he is a member of the International Department. He has handled many of the major United States antidumping and countervailing duty cases of the last three decades, representing foreign respondents and United States petitioners with equal frequency. In addition to litigating cases, Mr. Cunningham regularly advises foreign exporters as to how they may reduce their vulnerability to United States import relief cases, and counsels foreign governments on how supports may be structured so as to comply with WTO rules and United States countervailing duty laws. He also represents clients in connection with proposed antidumping and countervailing duty legislation in the United States and in other countries, and in connection with the negotiation of international rules governing import relief 
proceedings. On behalf of both United States and foreign clients, Mr. Cunningham provides advice and advocacy with respect to international trade policy decisions by the United States and other governments. Such representations involve bilateral and multilateral trade negotiations, market-access initiatives, legislation, and governmental policies in such trade-related areas as intellectual property, government procurement, standards, export controls, taxation, and issues relating to trade in services.

Meera Fickling has been a research analyst at the Peterson Institute since 2008 and works with Senior Fellows Gary Clyde Hufbauer and Jeffrey J. Schott. Her areas of research include climate change and trade issues, particularly in North America. She is co-authoring a book on NAFTA and climate change policy to be published in 2010. Her prior work at the Institute includes NAFTA and Climate Change: Legislate Nationally, Cooperate Regionally (paper presented at the C.D. Howe Institute, October 2009) and Setting the NAFTA Agenda on Climate Change (PIIE Policy Brief 09-18, August 2009). She graduated summa cum laude from the College of William and Mary, where she majored in economics.

Kathryn Friedman serves as director of Law and Policy Research at the UB Regional Institute. In addition to publishing research on international law and governance related to the Canada-United States relationship, Friedman serves as direct program manager for the institute's Canada-United States research program, examining issues including border governance as foreign policy, comparative commercial and passenger flows across the northern border, and international cross-boundary collaboration in the environmental context. She frequently speaks on binational and international issues to both academic and non-academic audiences, including policymakers in Canada and the United States.

Friedman, a practicing attorney, is an adjunct professor at the University at Buffalo School of Law, where she teaches courses on international trade, immigration, and NAFTA. She is a member of the Advisory Council for the Niagara Observatory at Brock University, Women in International Security, and the Small Business Association International Trade Task Force. Friedman also served as vice chair of the International Law and Practice Section of the New York State Bar Association.

In addition to receiving a $\mathrm{Ph} . \mathrm{D}$. in political science, with concentrations in international relations and comparative political economy, Kathryn graduated magna cum laude from the University at Buffalo School of Law where she served as an international law fellow and as editor-in-chief of the Buffalo Law Review. She received the Carlos C. Alden Award for greatest contribution to the Law Review and the Law Faculty Award for outstanding contributions to the law school. Upon graduating from law school, Friedman served as confidential law clerk to an associate judge on the Court of Appeals of New York.

Dr. David T. Fung is the chairman and CEO of the ACDEG Group of companies. He has partnerships in forest products, biomass energy, chemicals, electrical power cogeneration, agric-foods, marine equipment, OEM parts manufacturing, and packaging wastes recycling in North America, Europe, and Asia. He obtained his bachelor, master, and doctorate degrees in chemical engineering from McGill University and completed the senior business executive program at Queen's University. Dr. Fung is currently co-chair of the Members of the Canada Foundation for Innovation, vice chair of the Canada China Business Council, senior fellow of the Asia Pacific Foundation, and past president of the Canadian Society for Chemical Engineering. He is also a member of the national board of directors of Canadian Manufacturers \& Exporters (immediate past chair), Canadian Standards Association Group (CSA), Canadian Green Chemistry \& Engineering Network, International Science and Technology Partnership Canada (chair of China Subcommittee), CentrePort Canada Inc., and the Western Canadian Transportation System Strategy Group.

Jon Groetzinger graduated with an A.B., magna cum laude in 1971 from Middlebury College and earned his J.D. with Certificate in International Legal Affairs in 1974 from Cornell University. Professor Groetzinger teaches courses in International Business Transactions, International Trade and Development, 
Business Associations for LL.M.'s and Doing Business in the U.S. He is U.S. national director of the Canada-United States Law Institute, associate director of the Case Abroad at Home program, and director of China Legal Programs. He founded and advises the Vis International Arbitral Moot team. Before becoming a full-time faculty member, Professor Groetzinger taught Case LL.M. candidates for more than a dozen years. With more than thirty years of international business practice experience, he has served as senior vice president, general counsel, and secretary of American Greetings, listed on the New York Stock Exchange. Prior to American Greetings, he was president and chief international counsel for international operations at aerospace giant Martin Marietta (now Lockheed Martin). He has also been CEO of other domestic and international businesses. Prior to becoming in-house counsel at Martin Marietta, Mr. Groetzinger practiced international corporate law in Boston. He has chaired national and regional General Counsel associations, appeared on TV, and been quoted on international corporate matters in Forbes, USA Today, China Post, Times of India, ABC, CBS, and NBC News, among other media.

Lawrence L. Herman, B.A., LL.B., is a graduate of the University of Toronto Law Faculty (1969). As senior counsel to Cassels Brock \& Blackwell LLP, Mr. Herman's practice concentrates on international trade, investment, and business transactions. He has acted for private sector clients, governments, and international agencies, dealing particularly with the GATT/WTO, FTA, and NAFTA, and he appears as counsel before dispute-resolution bodies under the NAFTA, as well as before the Canadian International Trade Tribunal, the courts, and Parliamentary committees. He is the director of the Task Force on Trade and Investment of the World Energy Council, London, United Kingdom. Lawrence Herman is repeatedly listed in the Lexpert/American Lawyer Guide to the 500 Leading Lawyers in Canada and in Chambers Global Leading International Lawyers. He has lectured in international law at several Canadian law schools. Together with numerous articles in legal and business journals, Mr. Herman is the author of Canadian Trade Remedy Law \& Practice (1997) and Canadian Trade Law (Thomson-Carswell, 2008). His third book, Export Controls \& Economic Sanctions, was published in 2010.

Ian Holloway, Ph.D., Q.C., was the associate dean at the Australian National University before joining the Faculty of Law at The University of Western Ontario as dean in 2000. Prior to moving into teaching, he spent a number of years in private practice in Halifax. He also served as the clerk to the chief justice of the Federal Court of Canada. Professor Holloway's teaching and research interests are in the areas of administrative law and legal history. He has published extensively, and he is one of the contributors to. the Oxford Companion to the High Court of Australia and the Oxford Companion to Australian History. $\mathrm{He}$ is also the author of Natural Justice and the High Court of Australia: A Study in Common Law Constitutionalism, and co-author of Laying Down the Law: the foundations of legal reasoning, research and writing in Australia (4th ed., 1996; 5th ed., 2001). In 1999, he was awarded the Vice-Chancellor's Award for Excellence in Teaching. In 2003, he was elected to membership in the American Law Institute, and in 2005, he was appointed Queen's Counsel. He is an alumnus of the Advanced Executive Program at the Kellogg School of Management. He received his BSc (1981) and LLB (1985) from Dalhousie, his LLM (1992) from University of California: Berkeley, and his Ph.D. (1999) from Australian National University. He was called to the Bars of Nova Scotia (1986) and Ontario (2003).

Christopher H. Hunter joined Parker-Hannifin Corporation sixteen years ago. Parker is a Fortune 500 company with over $\$ 11$ billion in sales, and a leader in the motion and control industry, with operating groups focused on markets in Aerospace, Automation, Fluid Control, Sealing solutions, Hydraulics, Filtration, Climate Control, and Instrumentation. Mr. Hunter develops intellectual property strategy for new product development in Parker's Aerospace and Filtration Groups, including pursuing and managing the world-wide development of a strong and meaningful patent, trade secret, trademark, and copyright portfolio. He is also responsible for the enforcement of Parker's intellectual property rights against infringers, and ensuring that Parker does not infringe the patent and other intellectual property rights of others. His practice also deals with developing strong business relations with suppliers, customers, and 
technology developers, including the drafting and negotiation of licensing and development agreements. Before Parker, Mr. Hunter was an associate with Calfee, Halter \& Griswold, Cleveland, Ohio, in their intellectual property department, primarily focusing on patent prosecution. He is currently an adjunct professor at Case Western Reserve Law School, and is past president of the Henry T. King, Jr., Greater Cleveland International Lawyers Group.

Dr. Maureen Irish teaches international economic law, international business transactions, CanadaUnited States legal issues, and private international law (conflicts). She is the author of Customs Valuation in Canada (1985), as well as editor or co-editor of The Auto Pact: Investment, Labour and the WTO (2004), International Trade \& Intellectual Property: The Search for a Balanced System (1994), and The Legal Framework for Canada-United States Trade (1987). Dr. Irish has served on dispute settlement panels under the Canada-United States Free Trade Agreement and the North American Free Trade Agreement.

Stephanie Lariviere is the regulatory manager for both Erie James Ltd. and Sunsation Acres Inc. Her responsibilities for both companies encompass the bio-security and food safety programs. She also is a four-year serving member of the Ontario Greenhouse Vegetable Growers (OGVG) Food Safety Committee and recently joined the Canada Produce Marketing Association Food Safety Committee in 2010. She has also been nominated to serve on the Canadian Horticultural Council's On Farm Food Safety Technical Working Group Committee for 2011.

Ms. Lariviere obtained her honours bachelor of commerce in management and a bachelor of arts in English from the University of Windsor, Ontario in 2001. She has been working in the food industry for over ten years. Her roles began in administration where she was exposed to most elements of this integrated greenhouse and vegetable marketing company. She has been responsible for inventory and production records, and her expertise presently includes managing the compliance of all regulatory programs.

Ms. Lariviere's role includes overseeing both food safety and food security, through the C-TPAT program that has been verified by U.S. Homeland Security for the past five years. She is certified in Hazard Analysis Critical Control Points-based programs. These food safety programs that their companies utilize are globally recognized under the Global Food Safety Initiative. Stephanie personally has become a certified Safe Quality Food Practitioner in 2008. She is the driving force behind her company's longstanding commitment to improving processes to ensure the supplies of fresh produce are safe and consistently meet their customer's requirements. In 2009, Ms. Lariviere's company and the OGVG received the Ontario Premiers Award for Agri-food Innovation and Food Safety Excellence.

Wilbur Leatherberry spent three years as a Legal Aid attorney and two years as a legislative assistant to Ohio Congressman Louis Stokes before joining the Case Western Reserve University School of Law faculty in 1973. He served as associate dean for academic affairs from 1992 to 2000 . He teaches Contracts, Dispute Resolution, Insurance, Sales, and Secured Transactions. Professor Leatherberry has been active in the field of Alternative Dispute Resolution and helped to design the ADR program for the U.S. District Court for the Northern District of Ohio. He frequently serves as a neutral in mediation or arbitration processes, both private and court-annexed. In addition, he conducts ADR training programs both for neutrals and advocates. He received his A.B. (1965) and J.D. (1968) from Case Western Reserve.

Jessica LeCroy, an American-trained lawyer and former senior U.S. diplomat, provides strategic business and policy advice to Bennett Jones and its clients who are interested in pursuing global growth and business opportunities with emerging economies. 
A former visiting senior fellow in geo-economics at the Council on Foreign Relations in New York, Ms. LeCroy also served as national security advisor to the secretary of the treasury and U.S. consul general in Toronto. Her overseas assignments include Iraq, Bosnia, Georgia, The Netherlands, and Nicaragua. She has been awarded a Salzburg Seminar Fellowship in international arbitration, an American Political Science Association Congressional Fellowship, and several U.S. State Department Awards. She is a member of the International Women's Forum, a graduate of the Directors' Consortium, and serves on the advisory boards of the Canada-United States Law Institute and privately-held companies. She is a member of the Texas State Bar Association.

She received her B.A., with distinction (1975), from the University of Virginia (USA), her J.D. (1980) from Boston University School of Law (USA), and her M.S. (2000) from National Defense University, and has completed post-graduate work at Oxford University (Trinity College), University of London (King's College), Johns Hopkins School of Advanced International Studies, and the Peace Palace at The Hague.

William D. Manson is deputy general counsel of The Lubrizol Corporation, a global specialty chemical company with manufacturing facilities around the world. Since joining Lubrizol in 1995, he has advised his global business clients on questions regarding legal compliance, contracts, and product distribution. Prior to joining Lubrizol, Mr. Manson spent ten years in private practice as a member of the litigation section of an international law firm. He received his BA and his MA (economics) from Bowling Green State University in 1974 and 1975 and his Ph.D. in economics from Virginia Tech in 1980. From 19781982, he served on the faculty of the Department of Economics at The Ohio State University. He was an Olin Fellow at the Center for Law and Economics at Emory University from 1982-1985 and received his law degree, with distinction, from the Emory University School of Law in 1985, where he was an articles editor on the Emory Law Journal and received the Order of the Coif and the Order of the Barrister.

James P. Mcllroy's career in law, international trade, and government spans three decades. He has worked at several leading United States and Canadian law firms. A former senior policy advisor to the Canadian Minister for International Trade and Prime Minister's Office, Mr. McIlroy helps clients deal with the departments of Finance, Industry, Agriculture, Foreign Affairs and International Trade, the Canada Border Services Agency, and the Canadian International Trade Tribunal. He is active in negotiations and disputes, including the World Trade Organization. Mr. Mcllroy speaks and publishes widely, including in the Journal of World Investment and Trade. He is bilingual and holds a B.Sc. in political science from Université de Montréal, a Maitrise from the Sorbonne, and an LL.B. from Osgoode Hall Law School. Mr. Mcllroy serves on several boards, including the Canada-United States Law Institute. He has been a member of the Ontario Bar since 1983.

Paul Meyer is senior counsel with the legal department of Towers Watson, a global consulting firm. He has managed claims, litigation, and risk management issues throughout the United States, Canada, the Caribbean, and Europe since 1994.

$\mathrm{He}$ is a regular speaker at professional associations throughout the world on risk management, professional standards, electronic discovery, data privacy laws, arbitration, and the challenges facing inhouse attorneys of global companies. Prior to practicing in-house, he was an associate at the Washington, D.C. office of Deacons - Graham \& James. Before that, he maintained a trial practice at a leading real estate firm in the metropolitan Washington area.

Paul is currently a member of the Sedona Conference's "Working Group 6: International Electronic Information Management, Discovery and Disclosure," the Corporate E-Discovery Forum, the Advisory Board of the Canada-United States Law Institute, and Association of Corporate Counsel and the Washington Metropolitan Area Corporate Counsel Association. 
Paul received his B.A. in philosophy, cum laude, from the University of Pittsburgh's Honors Program. He graduated from Case Western Reserve University School of Law, where he served for two years on the Law Review (staff and Associate Editor) and authored a Note published at 33 Case W. Res. L. Rev. 294-325. In his third year of law school, Paul attended the University of Western Ontario's Law School and Graduate School of Business Administration as Canada-United States Law Institute Scholar. He completed the Harvard Leadership Development Program sponsored by Watson Wyatt at the Harvard Business School in 1997.

Paul is admitted to practice in Virginia, Maryland, the District of Columbia, and the U.S. Tax Court, the U.S. Court of Appeals for the Sixth Circuit, and numerous U.S. District and Bankruptcy Courts.

R. Richard Newcomb is a partner based in Washington, D.C. where he is chair of the International Trade practice group. He comes to DLA Piper from Baker Donelson, where he chaired the International group.

Mr. Newcomb has had considerable international experience dealing with target governments, front-line states, like-minded allies, multilateral organizations (the United Nations, the European Union and others), financial and business communities worldwide, and others who are responsible for compliance with asset controls and economic sanctions and embargo programs. He is adept at handling regulatory procedures relating to international transactions, including navigating the requirements of the Committee on Foreign Investment in the United States (CFIUS), the Bank Secrecy Act (and anti-money laundering laws), Export Administration Act, Anti-Boycott compliance, United States customs law, and the relevant portions of the Patriot Act.

From 1987 to 2004, Mr. Newcomb served as director of the Office of Foreign Assets Control (OFAC) of the United States Treasury Department. Throughout his tenure, Mr. Newcomb oversaw the administration and enforcement of thirty-nine economic sanctions programs in furtherance of United States foreign policy and national security goals. His leadership guided the agency through many of the major foreign policy challenges the nation has experienced in the past two decades, from the advent of multilateral sanctions against Iraq in 1990-coupled with a protective blocking of approximately $\$ 50$ billion in Kuwaiti assets-to the transformation of the agency after the attacks of September 11, 2001, to track and disrupt terrorist organizations and their financing networks.

In his time at OFAC, Mr. Newcomb was responsible for implementing economic sanctions and asset controls against Burma, Cuba, Iran, Liberia, Libya, Sudan, Zimbabwe, narcotics traffickers in Colombia, and narcotics kingpins and their networks operating worldwide, as well as for maintaining the prohibition against financial transactions with Syria. Other economic sanctions that he implemented and saw through to completion included programs targeting the Taliban, North Korea, Serbia, Angola, Haiti, South Africa, Panama, Vietnam, and Cambodia.

Throughout his time at OFAC, the agency played a significant role within the domestic and the international communities, confirming that economic sanctions can be an effective tool of international diplomacy. The strategies developed under his leadership and supervision for implementing sanctions and targeting terrorists are among the principal tools used today to wage the war on terrorism and terrorist financing.

Prior to his assignment with OFAC, Mr. Newcomb held a number of other positions in the Treasury Department, including director of the Office of Trade and Tariff Affairs and deputy to the assistant secretary (Regulatory, Trade and Tariff Affairs), where he was the principal advisor to the assistant secretary for enforcement on customs, international trade, commercial, and regulatory matters. 
President Ronald Reagan awarded him the Presidential Rank Meritorious Executive Award. Both President George H. W. Bush and President Bill Clinton honored him with the Presidential Rank Distinguished Executive Award. He has also received the Department of the Treasury Management Excellence Award and the Albert Gallatin Award. The Department of the Navy awarded him its Superior Public Service Award. During his tenure at OFAC, the American Bar Association Section of International Law and Practice presented the agency with its Award for Outstanding International Law Office. When Mr. Newcomb departed the Treasury Department, he was awarded The Treasury Medal by Secretary John Snow "in recognition of singular accomplishments and leadership."

Robert Noble assumed his duties as Canada's consul general, in Detroit, on September 5, 2006. As the consul general of Canada based in Detroit, Robert Noble represents Canada in the States of Michigan, Indiana, Ohio, and Kentucky. The Canadian Consulate General which he heads, promotes Canadian interests--trade, investment, the environment, culture, and academic relations being among the principal ones. The office also provides consular, passport, visa, and immigration services.

Mr. Noble served previously at the Canadian Consulates General in New York City and Boston. Mr. Noble began his career in the Canadian Foreign Service in 1974. He has served in a variety of trade and commercial advisory and policy positions in Ottawa, and his foreign assignments include postings as commercial minister/counselor at the Canadian Embassies in Madrid, Spain, and in Mexico City. He was Canada's ambassador to Gabon from 1997 to 2000. In addition to his public service, he spent four years as director of Government Liaison at the Canadian Exporters Association.

Hon. James S. Peterson, P.C. has served in the government of Canada as minister of International Trade, secretary of state (International Financial Institutions) (1997-2002), and chair of the House of Commons Standing Committee on Finance (1993-97). As a former minister of International Trade (2003-06), he represented Canada at the World Trade Organization's Doha round of negotiations. He retired from the House of Commons in 2007 after twenty-three years of service as the member of Parliament for Willowdale (Toronto). Before entering public life, he had a distinguished career as both a legal scholar and teacher and as a practitioner of international tax and business law. He was also a consultant for the U.N. Industrial Development Organization. He was appointed head of negotiation for Ontario in its efforts to reduce barriers to trade, investment, and labor mobility, and to enhance economic cooperation with Quebec.

$\mathrm{He}$ is the author of numerous articles and studies for Canadian and foreign publications. He received a DCL (1970) from McGill University; an LLM (1967) from Columbia University; a Certificate d'Assistance (1966) from L'Académie de Droit International, The Hague; a Diplôme d'Etudes de Civilisation Française (1966) from La Sorbonne; and a BA (1963) and LLB (1964) from The University of Western Ontario.

David Porter teaches advanced securities regulation. Prior to becoming a visiting professor at Case Western Reserve University School of Law, he was at Jones Day, practicing in the areas of corporate governance, disclosure, and corporate finance. He has been recognized for client service (2007 BTI Client Service Team All-Stars), technical skills (2005-07 Chamber's USA-Leading Lawyers for Business-Ohio/Corporate/ M\&A), and as an Ohio Super Lawyer. Public companies, in diverse industries, call on him for corporate governance and securities disclosure advice. Mr. Porter chairs the Corporation Law Committee of the Ohio State Bar Association and has been a leader for numerous legislative enhancements to Ohio's corporate statutes. He is a member of the ABA (Business Law Section), Ohio State Bar Association (Corporation Law Section), and Cleveland Metropolitan Bar Association (Securities Law Section, former chair). Mr. Porter serves as a trustee of the Cleveland Bar Foundation, Reaching Heights Foundation, and Great Lakes Theater Festival (past president). 
He regularly teaches a nationally offered seminar on MD\&A for Executive Enterprises Institute and also writes and lectures on securities, corporate governance, and corporate structuring. He is a graduate of Case Western Reserve University.

Robert Rawson counsels and litigates issues concerning antitrust and trade regulation. He has handled cases involving mergers and acquisitions, price discrimination, monopolization and attempted monopolization, price-fixing, class actions, intellectual property cases raising antitrust issues, and takeovers. In addition, he has significant experience in general commercial litigation. In his most recent trial he led a team for R.J. Reynolds Tobacco to a defense jury verdict on a price discrimination claim in which a tobacco retailer sought several billion dollars in damages allegedly caused by differences in prices offered to it as opposed to those offered to competitors (N.D. Ill. October 15, 2004).

For twenty years, Dean Rawson served his alma mater Princeton as a member of its Board of Trustees, during the last thirteen of which he served as chairman of the Executive Committee of the Board. He is currently chairman of the National Civic League, which assists communities and local governments to operate more successfully and efficiently, and chairman of the Northeast Ohio Council on Higher Education, a consortium of twenty-six educational institutions working to enlarge their impact in the region. He has been a member of the Board of the Lawyers Committee for Civil Rights and is past chairman of the Cleveland Initiative for Education, which marshals private resources in aid of the Cleveland Public Schools. Dean Rawson is a member of the ABA (Antitrust Law, Litigation, and Law Practice Management Sections), the Ohio State Bar Association (Antitrust Section), the Cleveland Metropolitan Bar Association, and the Bar Association of the District of Columbia.

J. Michael Robinson, Q.C. is counsel in the Toronto office of Canadian national and international law firm, Fasken Martineau DuMoulin LLP. There he advises on international business, trade, and investment law, including Public/Private Partnerships projects for infrastructure in developing countries. Mr. Robinson is also an adjunct professor at Osgoode Hall Law School, of York University, Toronto and an adjunct faculty member at The University of Western Ontario Faculty of Law, London, Ontario. There he teaches international business, trade, and investment law. He publishes and speaks widely in Canada and abroad on private international law subjects and was for over thirty years active at senior committee and executive levels of the Section on Business Law of the International Bar Association (London). Mr. Robinson is a long time participant in the Canada-United States Law Institute and is currently a member of the Executive Committee of its Advisory Board.

Christopher Sands is a senior fellow at the Hudson Institute, where he specializes on Canada and United States-Canada relations, as well as North American economic integration. $\mathrm{He}$ is also a professorial lecturer at the Johns Hopkins University School of Advanced International Studies, an adjunct professor in government at the American University School of Public Affairs and lectures at the Foreign Service Institute of the U.S. Department of State and for the U.S. Department of Homeland Security.

From 2002 to 2007, Dr. Sands was the director of strategic planning and evaluation at the International Republican Institute (IRI), a core institute of the National Endowment for Democracy and implementer of democracy and governance programs of the U.S. Agency for International Development and Department of State. At IRI, he was involved in evaluations and assessments of programs in Iraq, Pakistan, Indonesia, and Slovakia and conducted training seminars for new policy research institutes and think tanks in emerging democracies. In 1993, Dr. Sands began a long association with the Center for Strategic and International Studies (CSIS) where he focused on United States-Canada relations and North American integration issues, including a major study with Sidney Weintraub of The North American Auto Industry under NAFTA (CSIS Press, 1998). 
In 1999-2000, Dr. Sands was a Fulbright Scholar and visiting fellow at the Norman Paterson School of International Affairs at Carleton University in Ottawa. Dr. Sands holds a B.A. in political science from Macalester College in St. Paul, Minnesota, and an M.A. and Ph.D. in Canadian studies and international economics from the Paul H. Nitze School of Advanced International Studies at the Johns Hopkins University. He is a member of the American Political Science Association, the International Studies Association, and the Association for Canadian Studies in the United States.

Michael P. Scharf served as a member of the international team of experts that provided training to the judges of the Iraqi High Tribunal in 2004-05; in 2006, he led the first training session for the investigative judges and prosecutors of the newly established U.N. Cambodia Genocide Tribunal; and in November 2008, he served as special assistant to the prosecutor of the Cambodia Tribunal. He is currently co-leader of a USAID-funded project to assist the government of Uganda in establishing a special war crimes chamber and truth commission. In February 2005, Prof. Scharf and the Public International Law and Policy Group, a Non-Governmental Organization he co-founded, were nominated for the Nobel Peace Prize by six governments and the prosecutor of an International Criminal Tribunal for the work they have done to help in the prosecution of major war criminals, such as Slobodan Milosevic, Charles Taylor, and Saddam Hussein. During the elder Bush and Clinton Administrations, Prof. Scharf served in the Office of the Legal Adviser of the U.S. Department of State, where he held the positions of attorney-adviser for Law Enforcement and Intelligence, attorney-adviser for U.N. Affairs, and delegate to the U.N. Human Rights Commission. A graduate of Duke University School of Law (Order of the Coif and High Honors), and judicial clerk to Judge Gerald Bard Tjoflat on the 11 th Circuit Federal Court of Appeals, Prof. Scharf is the author of over seventy scholarly articles and thirteen books, including three that have won National Book of the Year Awards. His latest book is Shaping Foreign Policy in Times of Crisis (Cambridge University Press, 2010). Prof. Scharf has also testified before the U.S. Senate Foreign Relations Committee and the House Armed Services Committee, and appears frequently in the national and international media.

Jeffrey Shafer is an associate in the Tax Group at Blakes. He practices in all areas of Canadian domestic and cross-border income tax law, with a particular focus on mergers and acquisitions, domestic and international corporate and trust reorganizations, private equity investment, and the taxation of various investment vehicles. His practice also includes acting for taxpayers at all levels in the tax appeals process.

Jeffrey regularly speaks and writes about Canadian domestic and cross-border income tax issues. He is an adjunct professor at the University of Toronto Faculty of Law for the current academic year. He is also a member of the Canadian Bar Association, the Ontario Bar Association, the Canadian Tax Foundation, and the International Fiscal Association.

Jeffrey obtained his J.D. (with honours) from the University of Toronto. Before attending law school, he received his honours bachelor of applied science in mechanical engineering (dean's list) with an option in management sciences from the University of Waterloo.

Brett Smith joined the Center for Automotive Research in 2000 after twelve years at the University of Michigan's Office for the Study of Automotive Transportation (OSAT). Over the past twenty years, Mr. Smith has divided his research efforts between automotive industry analysis, and advanced powertrain technology and strategy. He is currently leading several research efforts on advanced powertrain technology, including such projects on energy storage policy and plug in electric vehicle infrastructure issues. He is also program director for the Business of Plugging In, a conference held annually in Detroit, Michigan. Mr. Smith has authored numerous reports ranging from materials for education and training to aftermarket strategies. 
Robert Strassfeld clerked for Judge Harrison L. Winter of the U.S. Court of Appeals for the Fourth Circuit and then practiced for three years at the Washington, D.C. firm, Shea \& Gardner before joining the Case Westem Reserve University School of Law faculty in 1988. Professor Strassfeld teaches Torts, Federal Courts, Labor Law, and Legal History. He has published articles on theoretical aspects of causation in the George Washington and Fordham law reviews and on law and the Vietnam War in the Wisconsin, North Carolina, and Duke law reviews. He is coauthor of Understanding Labor Law. His current research includes continuing work on the legal history of the Vietnam War and a history of African American lawyers in Cleveland. He received his B.A. in 1976 (Wesleyan University), his M.A. in 1980 (Rochester), and his J.D. in 1984 (Virginia).

Laurie A. Tannous of Sandler Travis creates and maintains global business development strategies and processes for all business lines. She also participates in new service/product development, provides direction and coordination to firm professionals regarding business development activities, and provides leadership in the development of firm materials, Web site, and branding.

An accomplished lawyer within the industry since 2004, Ms. Tannous practiced immigration and corporate law in Ontario as a barrister and solicitor prior to joining STTAS. In 2006, she became certified as a special legal consultant in the state of Michigan. She also worked for seven years for the Canada Border Services Agency as a customs and immigration officer responsible for the enforcement of Canadian customs and immigration laws and regulations. Ms. Tannous is an accomplished lecturer and a requested presenter at many trade and industry forums on matters related to marketing strategies, networking, immigration, and other customs and trade related matters.

Greg Wilkinson is the president of Third Oak Associates Inc., a strategy, communications, and advocacy consultancy based in Toronto. Before retiring from NOVA Chemicals in 2010, his career included executive roles in both Canada and the United States. He was NOVA Chemicals' senior public policy representative in Canada and the United States, and was responsible for government, media, and community relations, as well as corporate and marketing communications. Greg is the chairman of the board of the Canadian Plastics Industry Association, past chairman of the Public Affairs Committee of the Chemistry Industry Association of Canada, and also served on the Board of the Carnegie Science Center in Pittsburgh and the Pittsburgh Regional Canada Forum.

Greg was born in Guelph, Ontario, and attended The University of Western Ontario, earning his bachelor of arts in history. His career includes marketing and sales roles with Canadian Pacific, transportation management with PanCanadian Resources, and a series of leadership roles with NOVA Chemicals prior to founding Third Oak Associates Inc.

Margaret Ann Wilkinson is director of the Area of Concentration in Intellectual Property, Information and Technology Law. Prior to her graduate studies (supported, inter alia, by a Social Science and Humanities Research Council doctoral fellowship), Professor Wilkinson practiced law in Toronto for several years. She first joined the Faculty of Law at The University of Western Ontario in 1991. In 1992, she became jointly appointed to the Faculty of Law and the then Graduate School of Library and Information Science, now the Faculty of Information and Media Studies. She retains her supervisory status for doctoral students in Library and Information Science and her supervisory status in the Graduate Program in Law, but is, since 2007, fully appointed to the Faculty of Law. She is also an adjunct professor at The Richard lvey School of Business. Her thesis on The Impact upon Affected Organizations of the Ontario Freedom of Information and Protection of Privacy Act, 1987 won the American Society for Information Science Doctoral Dissertation Award. Professor Wilkinson has spoken and published in the areas of intellectual property, information and media law, and information policy, including health information policy, as well as in the areas of management, professionalism, and professional ethics. 
E. Miller Williams, Jr. of Ernst \& Young consults with multinational corporate clients on a national basis regarding complex transfer pricing matters with an emphasis on international transfer pricing controversy, advanced pricing agreements (APA), competent authority, and transfer pricing planning and structuring.

Mr. Williams has over eighteen years of transfer pricing consulting experience (five with the government and thirteen in private practice) with companies in a variety of industries. His industry experience includes work with paper and pulp, building products, pharmaceutical, semiconductors, software, packaging, retail, consumer products, motor vehicles, automotive parts, heavy equipment, and industrial machinery. Mr. Williams is a frequent speaker at Council for International Tax Education Seminars and other tax seminars and has authored a number of transfer pricing articles.

Earlier, Mr. Williams headed the Southeast transfer pricing practices of a previous Big 5 Firm and of one of the current Big 4 Firms in Atlanta. Prior to private practice, Mr. Williams served as a senior attorney in the Office of Associate Chief Counsel (International) for the IRS in Washington, D.C. working on a variety of transfer pricing and international tax matters. As a member of that office, he worked in the APA Program where he acted as lead attorney on many APA cases and as advisor to the director on APA procedures.

Mr. Williams received his LLM in taxation from Emory, his J.D. from Stetson University College of Law and his undergraduate degree from Vanderbilt. Prior to working for the IRS, he served as an officer and attorney in the U.S. Army Judge Advocate General's Corps where he held positions as a prosecutor, defense attorney, and administrative law attorney. He is a member of the Georgia Bar Association and the American Bar Association Tax Section, and is a board member and officer of the Georgia Council for International Visitors and board member of the Atlanta Area Council of the Boy Scouts of America. 


\title{
CANADA-UNITED STATES LAW INSTITUTE ANNUAL CONFERENCE
}

\author{
On \\ The Canada-United States Regulatory Regime: \\ REVIEW, REFORM, RECOVERY
}

Cleveland, Ohio

April 8-10, 2010 
. 